\title{
Recreational Wayfaring in the Mountains
}

Chiara Kirschner

\section{(2) OpenEdition}

\section{Journals}

Electronic version

URL: https://journals.openedition.org/rga/7397

DOI: $10.4000 /$ rga.7397

ISSN: $1760-7426$

Translation(s):

L'itinérance récréative en montagne - URL : https://journals.openedition.org/rga/7387 [fr]

Publisher:

Association pour la diffusion de la recherche alpine, UGA Éditions/Université Grenoble Alpes

Electronic reference

Chiara Kirschner, "Recreational Wayfaring in the Mountains", Journal of Alpine Research / Revue de géographie alpine [Online], 108-3 | 2020, Online since 14 January 2021, connection on 08 December 2022. URL: http://journals.openedition.org/rga/7397 ; DOI: https://doi.org/10.4000/rga.7397

This text was automatically generated on 8 December 2022.

\section{(c) (i) (9)}

Creative Commons - Attribution-NonCommercial-NoDerivatives 4.0 International - CC BY-NC-ND 4.0 https://creativecommons.org/licenses/by-nc-nd/4.0/ 


\title{
Recreational Wayfaring in the Mountains
}

\author{
Chiara Kirschner
}

1 Leaving home by bike and arrive in China a year later, traveling the Via Alpina on foot with the family during the summer, crossing the Moroccan Atlas in two weeks alternating ascent by walking and descent by paraglider, leaving home to a stroll in the vicinity of a few hours ... so many practices that may relate to recreational wayfaring. "May", because beyond what can be observed from the outside and which corresponds to the literal meaning of the term (to move along a route ${ }^{1}$ ), wayfaring in the geography and sociology of tourism also has a figurative meaning: the alternation of a route and wandering. What does this wandering consist of, which is the specificity of wayfaring?

2 Let's take a step back. The term wayfaring is not exclusive to (a few) geographers and sociologists of tourism. In fact, depending on the approach, it refers to a spatial practice, which can be recreational (Berthelot and Corneloup 2008), or to an intellectual practice, for example philosophy (Greisch, 2002). In both cases, the figure of the detour is at the heart of its meaning (it even gives the title of the collective work cited by Berthelot and Corneloup) and explains its part of wandering. In the first case (recreational wayfaring), the detour, and therefore the wandering, consists above all in modifying the itinerary planned in advance according to the unforeseen or personal appetence. In the second case (intellectual wayfaring), the detour consists of starting from a subject, moving the thought into an unknown, and generating new ideas, in other words to redefine the route, even sometimes the point of arrival, of this thought.

3 The ambivalence between spatial and intellectual detour makes it possible to consider a wide spectrum of detours, and wayfaring as a concept before even as a practice. To travel is to complete an inspiring journey (new ideas, knowledge, intuitions, experiences etc.) strewn with detours operated by thought, imagination, action. This concept makes it possible to reinterpret the practices which are manifested more and more in our contemporary societies beyond the only spatial and recreational level; and make it a prime ground for exploring the very concept of wayfaring. 
4 By closely studying recreational wayfaring, we see that the detour takes place in several dimensions: spatial, of course, but also socio-cultural, and existential. As we have seen, the spatial detour takes place via the change of itinerary, and the lengthening or shortening of its duration which derives from it (one could even speak in this case of a temporal detour).

5 The sociocultural detour takes place on a pragmatic level via experiments in terms of means of transport, cf. Corneloup and Mao, 2010; on the imaginary level via, for example, sensory immersion in the natural environment, cf. Berthelot and Corneloup, op.cit., and Corneloup, 2016; it can also consist of individual or shared reflection, the production of new ideas, or even the taking of initiatives. This is the case when we leave, as is often the case with itinerants, to escape the technologization of our contemporary societies, to adopt a frugal lifestyle, or even to spread ideas or to help the most destitute encountered on the road (Bourdeau speaks in this regard of hybridization between recreational and activist wayfaring and post-tourism, cf. 2012, Corneloup of transmodern wayfaring). The socio-cultural detour also takes place via the distraction of everyday life, or the curiosity to discover a new culture, or to find stimuli to its artistic production. From the point of view of the professionals, the sociocultural detour takes place when recreational wayfaring becomes an opportunity to promote the territories and heritage located between resorts / tourist sites, as well as the emergence of new forms of governance (Cahiers Espaces, 2012). The detour is then facilitated by technological mediations, for example geocaching ${ }^{2}$ (Boulaire and Cova, 2008), or by sensory and imaginary supports, as in the Sentiers de l'Imaginaire ${ }^{3}$ (Corneloup and Mao, op.cit.).

6 The existential detour takes place on the relational level via the search for an intimate correspondence with the Other, for example a traveling companion or inhabitant with whom one does not share either language or culture (Lallemand 2010). Kirschner (2017) has deepened the existential detour and its nuances depending on whether it is a question of relationship with the otherness of the body or of the environment: physical, material, human, event-based ... and the integration of this. Wayfaring then transforms into a path of initiation, of better self-knowledge, the emergence of a goal of personal evolution or transformation, and identification of one's new place in society (Kirschner, 2017, and other examples of existential wayfaring are presented in Mercier and Fonovich, 2012).

7 All these detours have a creative potential: the spatial creation of route variants; the cultural creation of new practices, territorialities, communities, new socioeconomic forms based for example on frugality; the existential creation of new trajectories of life. They also inspire artistic creation in itinerants thanks to the anecdotes and dramas they involve. Travel diaries, novels, films, etc., therefore constitute an inexhaustible source of inspiration for researchers, actors in the territories, and future itinerants.

Mountain recreational wayfaring has been discussed so far by some professionals and researchers in the human and social sciences in the figurative sense of the term. Their interest is mostly in its spatial and socio-cultural dimension, less in its existential dimension. Their research output consists, on the one hand, of studies on specific recreational wayfaring practices, and, on the other hand, on its management and mediation.

9 Regarding the practices, according to Amy, among the contemporary mountain practices resulting from mountaineering, only the free-ride is wayfaring, by 
transgressing the marked paths of the tracks, and by going to seek virgin slopes (spatial detour). Mountaineering has been associated with wayfaring, less by the intrinsic characteristics of this highly standardized practice than by the nomadic lifestyle that it implies (sociocultural detour, Amy in Berthelot and Corneloup, op.cit.). Kirschner (op.cit.), in line with Berthélot (2011), noted the various dimensions of recreational mountain wayfaring. On the one hand, the sensory and imaginary detour offered by this environment, and the ecological ethics that it encourages. On the other hand, the reference role that the mountain can have in a changing itinerary, both spatial and existential, as for example in the proximity wayfarings of Lionel André, which contribute to an artistic creation (http://lionelandre .blogspot.fr).

Concerning management, Tollis (in Berthelot and Corneloup, op.cit.) studied shared management, not necessarily commercial, between itinerants and actors of the Pacific Crest Trail in the United States. Other players activate natural or cultural resources (the Lavender and Mozart routes, etc.) to facilitate the imaginary detour. In the training courses to support mountain wayfaring studied by Andreux (in ibidem), we find the facilitation of sensory and imaginary detour in contact with the mountain environment. A recent scientific and artistic residency in three Regional Natural Parks of Auvergne Rhône-Alpes made it possible to develop a new form of territorial mediation for local recreational wayfaring in mid-mountain territories (provision of red wooden letters of different sizes for expressing detours in space), and to advance in research on existential detour (Kirschner 2020a).

11 An example of artistic creation resulting from recreational wayfaring in the mountains are the photographs of Dimitri Vazemsky, taken as part of this same residency (http:// www.itinerance.lettercamp.org/le-projet/).

This special issue sets itself the objective of better structuring and enriching the field of study (today very limited) of recreational mountain wayfaring through the exploration of all its detours (spatial, socio-cultural, existential), specific practices, management (governance, territorial development, mediation). It is organized according to the type of creation to which the wayfaring leads: spatial, cultural, existential, and artistic. It also helps to identify the role and contribution of the mountain environment to recreational wayfaring, and its status in the analysis of this practice.

13 Spatial creation is intimately linked to action. The authors who have looked into this have taken the decision not to dissociate the body and the environment through which it passes; they see this duo as a creative and orienting relationship. Tassart's paper opposes the bodily detour through the spontaneous knowledge of the body, which is at work in the practice of trail running, to the artificialization of our cities. This bodily detour consists above all in orienting oneself in one's body and in one's existence, in grasping its overall logic and coherence, in order then to become capable of orientation in space. Thanks to the variations in the relief, the mountain requires both an antigravity and rebalancing effort, and promotes the emergence of spontaneous knowledge of the body in those who run through it. Wayfaring can then inspire a reversal of urban planning to reconnect human beings with their creative capacity. This paper makes a new contribution - the orientation approach - to the analysis of bodily creativity at work in wayfaring, as a means of environmental awareness and decision-making (Kirschner 2018). The paper by de Potestad explores the status of the trail of travel on the snowpack, which is at the same time imprint, mediation, and representation of wayfaring. The trace always brings out the interpretive character of the practice. 
Following the history of the Mont-Blanc ascent maps, the author shows the place that is always left to the creativity of the body in relation to the labile nature of the trace in a glacial environment. In addition to the snowpack, the mountain offers the specificity of wayfaring the effect of the slope, which blocks the horizon from the gaze and forces the planned route to be updated. The trace as movement, like the line of Ingold (2011), which once again summons the creativity of the body.

The field of cultural creation in wayfaring is very vast, and includes territoriality, imaginary representation, and the creation of a new cultural form of wayfaring, different from transmodern wayfaring: hyper-wayfaring. Giroult's paper explores the relationship between practitioners of distance flight, which is only practiced in the mountains, to air and land space, and the territoriality that this practice produces. Spatial detours that deal with uncertainty and regulation and that end up building the route to reach the destination, technological mediation, symbolic investment of the departure and arrival sites and final narrative, create a singular territoriality that can be represented from of a "heat map". Distance flight has also given rise to a narrative production, in particular flight-bivouac wayfaring stories, which develops the cultural dimension of paragliding wayfaring: its imaginary, the opportunity for discovery. Guyon's paper explores the relationship between individual and tree in the context of walking in the forest, as a sensory immersion for therapeutic purposes and a manifestation of the transmodern culture of wayfaring, which values naturalness. According to the author, this immersion implies going astray, that is to say the estrangement from technological culture and the loss of consciousness or of selfcontrol, until the fusion in the community of trees (this practice is closer to wandering than to wayfaring, to meditation than to knowledge and transformation of oneself). Barna's paper explores the imaginary detour, and shows that it leads to the creation of a different culture of wayfaring in the Pyrenees compared to the Alps. The relatively low altitude, the wild nature (in particular the existence of numerous lakes) and the reduced presence of man in the Pyrenees would facilitate less competitive and more contemplative representations than in the Alps. Therefore, the Pyrenees are more suitable for wayfaring on foot than the Alps, the latter preferred by mountaineers. Adventure wayfaring in a wild world that still requires some stamina. Crossing the Pyrenees from the Atlantic to the Mediterranean is also tinged with an initiatory dimension. Szkutnicki and Mao's paper isolates and describes the practice of hyperwayfaring based on a study of Israeli backpackers in mountainous areas of Chile. This is an initiatory practice where spatial detours, experiments, cultural discovery, meeting with the inhabitants, that is to say opening to otherness, go along with frequentation of peers on site in "Israeli enclaves", as well as connection to one's own via internet, or anchoring in the familiar. Hyper-wayfaring also contributes to a technological and consumerist culture of this practice, which is distinct from the frugal culture and the ethical vocation of transmodern wayfaring. It makes a new contribution to the cultural approach to wayfaring, by highlighting the diversity of its contemporary forms. Next to transmodern wayfaring, based on the slowness and depth of the relationship with the practice environment (Kirschner 2020b), hypermodern wayfaring is observed which includes, in addition to these aspects, the speed of connection with the daily living environment.

15 Existential creation is revealed in this collection of papers thanks to the artistic production of a traveling monk. The paper by Bordessoule and Lompech proves the interest that wayfaring stories can have for the researcher and explores the singular 
spatiality both of the mid-mountain space which is crossed, and of the existence of the writer such as revealed by its wayfaring. Sensory and emotional detours are nourished by the search for a singular sense of the environment which opens up hope through the traces of a vanished time, childhood vacation spots, the evolution of agricultural techniques and of the landscape, the renewal of economic activity, friendly exchanges. They are doubled by the marginal and yet active status of Cézallier: a high summer pasture little used by local breeders and a hotspot for transhumance (another form of spatial wayfaring, not recreational).

What can be learned about the concept of wayfaring? These papers make it possible to deepen the notion of route in wayfaring, which takes place between, on the one hand, uncertainty or chance (for example, the ascents and clouds in paragliding) and, on the other hand, a frame (for example, the regulatory constraints of sports federations or other government bodies). One could even say, like Girault, that it is precisely the management of these two counterpoint parameters that builds the route, until reaching the desired destination. Uncertainty, everything unforeseen, and more generally any kind of limit to our initial project, would not only be the "salt" of wayfaring, but the very substance of it. It would not be so much to complete a route strewn with detours, but rather to construct a route using detours to reach your destination.

It is more precisely a process of co-creation between the individual and the environment, this latter understood in the broad sense: physical, material, human, event-based. The body - body awareness or proprioception as in the trail runner, and movement as in the cross-country skier - is confirmed as an essential resource in this process. Perception is the foundation of our thinking and acting in the world. And our action in the world can be seen as a creative meshwork that co-creates lines: the notion of line according to Ingold echoes the concept of wayfaring.

"The lines of my web, to the contrary, are themselves spun from materials exuded from my own body, and are laid down as I move about. You could even say that they are an extension of my very being as it trails into the environment - they comprise, if you will, my "wideware". They are the lines along which I live, and conduct my perception and action in the world." (Ingold 2011, p. 91)

Wayfaring is a committed mode of action that relies on the creativity of the body in relation to the whole environment. Other cognitive resources are at work in wayfaring and make up all its richness: the senses that we have seen at work in tree therapy, the emotional intelligence and the imaginary of itinerant hikers in the Pyrenees. All these alternative resources to analytical thinking are mobilized thanks to movement in a natural environment, but can obviously continue to be mobilized in any environment, once started. This does not mean that pause and thought are excluded from wayfaring (as we have seen among Israeli backpackers).

In the action of wayfaring, the way of orienting oneself (by the detour) counts more than the result (reaching the destination), because the detour enriches the experience, allows you to get to know yourself better, to do yourself good, gain confidence, motivate yourself, find a new direction, make a decision, take action. One's wayfaring story teaches others how to orient themselves better. Any geographic narrative can become a metaphor for a biographical narrative with which the reader can identify and from which he can draw inspiration, like that of the itinerant monk in the Monts d'Auvergne. 
If all the papers in this issue sweep the entire spectrum of the detour, while addressing other themes relevant to the study of wayfaring both as a practice and as a concept, some also manage to highlight the role specific to the mountain in wayfaring and in its analysis. When the study focuses on the spatiality of wayfaring, what matters are the physical characteristics of the mountain, inseparable from the physical action of the practitioner. Thus, the relief mobilizes the spontaneous knowledge of the trail runner's body and allows him to orient himself, the snowpack and the slope give a unique status to the trail of the cross-country skier. When the study deals with the territoriality of wayfaring, all the characteristics of the mountain environment are called upon. Paragliders interpret aerology, relief, departure and arrival sites, to produce unique representations of the earth's surface; itinerant hikers in the Pyrenees rely on the relative absence of man and landscape elements such as high-altitude lakes to build an imaginary of the wild.

21 However, mountains do not always play a key role in the practice or in the analysis of homelessness. Sometimes it only embodies a context. This is the case with tree therapy, where it is rather the trees - both plain and mountain trees - which allow the sensory immersion of practitioners; and the backpacking of young Israelis, interpreted as a form of hypermodernity. Finally, the mountain plays a supporting role for the existential dimension of wayfaring, that any other environment could play. A role of choice however, because the mountain environment is marked, for those who know how to interpret them, by the signs of an evolution of its configuration. This is particularly the case for the mid-mountain environment. Like an open history book, it stimulates associations of ideas between its trajectory and that of the practitioner: from growth to abandonment to rebirth, the Cézallier massif inspires resilience in the monk Cassingena-Trévedy.

\section{BIBLIOGRAPHY}

«Itinérance douce \& tourisme », Espaces tourisme \& loisirs, coll. Cahiers ESPACES n¹12, avril 2012

Berthelot, L., 2011.- « Les récits d'expérience pour mieux cerner les arrangements des pratiques itinérantes contemporaines - Dépassement de la logique dialectique et apport de l'aprèstourisme? ", in Cousin S., Gravari-Barbas M., Jacquot S., Tourisme - Concepts et méthodes à la croisée des disciplines, Actes des 1ères Doctoriales du Tourisme

Berthelot L., Corneloup J. (éds.), 2008.- Itinérance, du Tour aux détours : figure contemporaine des pratiques récréatives de nature, L'Argentière-la Bessée, Fournel

Boulaire C., Cova B., 2008.- « Attiser le "feu du jeu" postmoderne : le cas du géocaching et de ses zones liminoides », Sociétés, IV (102), p. 69-82. DOI : 10.3917/soc.102.0069

Bourdeau P., 2012.- « Cerner les contours d'un après-tourisme », in Martin N., Bourdeau P., Daller J. F., Migrations d'agrément : du tourisme à l'habiter, Paris, L'Harmattan, p. 17-33 
Corneloup J., 2016.- Sociologie des pratiques récréatives en nature. Du structuralisme à

l'interactionnisme, L'Argentière-la Bessée, Fournel

Corneloup J., Mao P. (éds.), 2010.- Créativité et innovation dans les loisirs sportifs de nature,

L'Argentière-la Bessée, Fournel

Greisch J., 2002.- Paul Ricœur. L'itinérance du sens, Grenoble, Million

Kirschner C., 2020a. - « Le rythme singulier et créatif de l'itinérance », EspacesTemps.net [En ligne], Laboratoire, 2020 | Mis en ligne le 22 avril 2020, consulté le 22.04.2020. URL : https:// www.espacestemps.net/articles/le-rythme-singulier-et-creatif-de-litinerance ; DOI : http:// doi.org/10.26151/espacestemps.net-eymb-y328

Kirschner C., 2020b.- « Le mouvement « slow », entre culture et éthique », in Lebreton F., Gibout C., Andrieu B., Vivre Slow. Enjeux et perspectives pour une transition corporelle, récréative et touristique, Nancy, PUN - Éditions Universitaires de Lorraine, 2020, p. 33-55

Kirschner C., 2018.- « La gestion de l'incertitude dans l'itinérance récréative : le corps créatif à l'œuvre ", Carnets de géographes [En ligne], 11 | 2018, mis en ligne le 15 septembre 2018, consulté le 05 novembre 2020. URL : http://journals.openedition.org/cdg/1607 ; DOI : https://doi.org/ $10.4000 /$ cdg. 1607

Kirschner C., 2017.- « Le projet transmoderne dans les itinérances récréatives. Un processus créatif intégratif de construction identitaire », Grenoble, Thèse de Doctorat en Géographie, Université Grenoble-Alpes

Ingold, T., 2011.- Being Alive : Essays on Movement, Knowledge and Description, London, Routledge

Lallemand S., 2010.- Routards en Asie. Ethnologie d'un tourisme voyageur, Paris, L'Harmattan

\section{NOTES}

1. In French, the word used to mean wayfaring is "itinérance ». As it conveys a specific meaning in English (homelessness), we choose the term of wayfaring. Nonetheless, the adjective « itinerant », less connotated, will also be used in this Introduction.

2. Geocaching is a recreational scavenger hunt practice that uses the mediation of satellite positioning to search for small, generally worthless items hidden in various locations, often along mountain trails.

3. Imaginary Trails

\section{AUTHOR}

\section{CHIARA KIRSCHNER}

Facilitation Créative - Reconversion Professionnelle et Conduite du Changement, www.artitinerance.com, chiara.kirschner@gmail.com 